\title{
Drug Purchases' analysis for COVID-19 treatment in Rio Grande do Sul
}

\author{
Natália Azeredo PAIM ${ }^{1}$ (D), Diego GNATTA ${ }^{2}$ iD \\ ${ }^{1}$ Faculdade de Farmácia da UFRGS, ${ }^{2}$ Departamento de Produção e Controle de Medicamentos e Programa de Pós-graduação em Assistência \\ Farmacêutica - Faculdade de Farmácia da UFRGS
}

Corresponding author: Paim NA, azeredo. paim@gmail.com

Submitted: 16-12-2020 Resubmitted: 12-04-2021 Accepted: 12-04-2021

Peer review: blind reviewers

\begin{abstract}
Objective: To evaluate quantities and costs of drug purchases related to COVID-19 treatment by regional governments under the Tribunal de Contas do Estado do Rio Grande do Sul (TCE-RS). Methods: A cross sectional study whose data collection was carried out in accordance with the data registered in the LicitaCon system of TCE-RS until September 29, 2020. The purchase processes of the pharmaceutical products hydroxychloroquine, chloroquine, ivermectin, nitazoxanide, vitamin D, vitamin C and zinc were analyzed in more detail. Results: There were 5,299 purchase processes registered on LicitaCon. Two hundred and fifty cases contained medications, of which 232 were analyzed, for only these met the study's inclusion criteria. At least one of the aforementioned pharmaceutical products was found in 142 (61.2\%) of the analyzed cases. Resulting in a total amount of \$661.913,52 for the analyzed processes. The most purchased drug was ivermectin, present in 80 of the acquisitions, adding up to $\$ 241.794,81$. The municipality of Garruchos, with an estimated population of 2,886, spent $\$ 6,858$ per inhabitant for the obtainment of ivermectin, consuming a total of $\$ 19.796,06$. Conclusions: The use of such pharmaceutical products for COVID-19 goes against the current available scientific evidence, the recommendations of WHO, the Rational Use of Medicines and Evidence-Based Health.
\end{abstract}

Key words: drug therapy; COVID-19; drug costs; financial resources in health; hydroxychloroquine; ivermectin.

\section{Análise das aquisições de medicamentos para o tratamento da COVID-19 no Rio Grande do Sul}

\section{Resumo}

Objetivo: Avaliar as quantidades e os valores das aquisições de produtos farmacêuticos relacionados ao tratamento da COVID-19 pelos órgãos jurisdicionados ao Tribunal de Contas do Estado do Rio Grande do Sul (TCE-RS). Método: Estudo seccional cuja coleta de dados foi realizada de acordo com os dados cadastrados no sistema LicitaCon do TCE-RS até o dia 29 de setembro de 2020. Os processos de compra dos produtos farmacêuticos hidroxicloroquina, cloroquina, ivermectina, nitazoxanida, vitamina $\mathrm{D}$, vitamina $\mathrm{C}$ e zinco foram analisados de forma mais detalhada. Resultados: Ao todo foram registrados 5.299 processos de compra no LicitaCon. Duzentos e cinquenta processos continham medicamentos, dos quais foram analisados 232, que cumpriam os critérios de inclusão do estudo. Em $142(61,2 \%)$ processos analisados foram localizados pelo menos um dos produtos farmacêuticos supracitados. O valor total dos processos analisados dos produtos farmacêuticos destacados foi de $\$ 661.913,52$. O medicamento mais adquirido foi a ivermectina, presente em 80 processos de compra, cujo somatório dos valores foi de \$241.794,81. O município de Garruchos, com população estimada de 2.886 , gastou $\$ 6,858$ por habitante para a compra de ivermectina, pelo valor total de $\$ 19.796,06$. Conclusão: A utilização de tais produtos farmacêuticos para a COVID-19 vai na direção contrária das evidências científicas disponíveis até o momento, das recomendações da OMS e do Uso Racional de Medicamentos e a Saúde Baseada em Evidências.

Palavras-chave: tratamento farmacológico; COVID-19; gasto com medicamentos; recursos financeiros em saúde; hidroxicloroquina; ivermectina.

\section{Introduction}

With the first case recorded in China in December 2019, COVID-19 had a rapid spread and was declared a pandemic on March $11^{\text {th }}$, 2020 by the World Health Organization (WHO). ${ }^{1,2}$ Up to November $30^{\text {th }}, 2020$, in Brazil, 6,335,878 individuals were diagnosed with the disease and 173,120 died as a result. ${ }^{3}$ On November $30^{\text {th }}, 2020$, Brazil was the third country with the highest number of infected people, only behind the United States and India, as well as the second country in number of deaths, behind the United States. ${ }^{4}$ 
As a consequence of the health emergency caused by the COVID-19 pandemic, research studies and tests were initiated to find vaccines capable of immunizing the population, as well as medications that assist in managing the symptoms or that promote a cure for the disease. According to the clinical trials virtual platform, until December $4^{\text {th }}, 2020,850$ drug interventions were recorded in clinical studies for COVID-19. ${ }^{5}$ The most used strategy for research is drug repositioning, which consists in testing medications already approved for other diseases, as information referring to the safety profiles of the drugs are known. ${ }^{6}$ For being a new disease and due to the fact that scientific knowledge is in its development stage, the recommended treatment is conducted to control the symptoms associated with the disease and in an attempt to prevent worsening of the patient's clinical condition and death. ${ }^{7,8}$

Meanwhile, some medications started to be publicized for the treatment of COVID-19, although there is no adequate scientific evidence. In an in vitro study, chloroquine and hydroxychloroquine presented antiviral action against SARSCoV-2. ${ }^{9}$ In March, a French study was published showing favorable results for the use of hydroxychloroquine in combination with azithromycin. ${ }^{10}$ After the publication of the article, many rulers and health professionals began to advocate the use of the medications for the treatment of COVID-19, despite the countless methodological weaknesses of the study. ${ }^{11,12}$ Such facts led many people to pharmacies to buy the drug in an unbridled manner, causing shortage of hydroxychloroquine and generating difficulty of access for patients who use the medications for the treatments approved by the National Health Surveillance Agency (Agência Nacional de Vigilância Sanitária, ANVISA). ${ }^{13}$ In response to the events, on March 20 th 2020 , the ANVISA classified chloroquine and hydroxychloroquine as special control medications, requiring the presentation of a prescription in two copies for their purchase. ${ }^{14}$

In addition to chloroquine and hydroxychloroquine, other medications were also publicized for the treatment of COVID-19 without adequate scientific basis. Ivermectin gained prominence due to a scientific article that demonstrated that the drug inhibited the replication of SARS-CoV-2 in vitro in a high and toxic dose, if administered to human beings. ${ }^{15}$ Nitazoxanide, a drug registered with the ANVISA as an antiparasitic, also demonstrated antiviral action in vitro. ${ }^{16}$ In July 2020, the ANVISA published RDC No. 405, which establishes the control measures for medications containing chloroquine, hydroxychloroquine, ivermectin and nitazoxanide, establishing rules to be observed regarding the prescription and dispensing of the medications, and withholding the prescription. ${ }^{17}$ However, in September of the same year, ivermectin and nitazoxanide were removed from the list of medications related in the resolution. ${ }^{18}$

Although there is no scientific evidence of a widely effective medication for COVID-19, the Ministry of Health (Ministério da Saúde, MS) adopted different actions. On March 27th, 2020 , an informative note was released on the use of chloroquine or hydroxychloroquine as an adjuvant therapy in the treatment of severe forms of COVID-19 in hospitalized patients. ${ }^{19}$ On May $20^{\text {th }}, 2020$, an MS guidance document was published for early medication handling by patients diagnosed with COVID-19, in which the recommendation for chloroquine or hydroxychloroquine, now associated with azithromycin, was expanded to treat mild and moderate forms of the disease. ${ }^{20}$ And on June $15^{\text {th }}, 2020$, the guidelines for the use of the medications were extended to children and pregnant women of any gestational age affected by the disease. ${ }^{21}$ In the same document, it is suggested to consider the administration of zinc sulfate concomitantly with the treatment with hydroxychloroquine and azithromycin, and the replacement of vitamin $D$ for patients with vitamin deficiency or presumption of deficiency. ${ }^{20}$

In Rio Grande do Sul (RS), the availability of medications through medical prescriptions to treat COVID-19 or as a prevention strategy was widely informed by the communication media. Municipalities adopted the distribution of pharmaceutical products for the treatment of COVID-19, such as hydroxychloroquine, chloroquine, ivermectin, vitamin D, zinc, nitazoxanide, vitamin $\mathrm{C}$ and oseltamivir. ${ }^{22}$ Although there are no scientific studies to support the use of such pharmaceutical products, the strategy is advocated by some physicians and the repercussion gained strength in the social networks, which were used by the population to exert pressure on governors and mayors to avail the medications to the population. ${ }^{23-26}$

Federal Law 13,979 of February $6^{\text {th }}, 2020$, which provides for the measures to cope with the public health emergency of international importance resulting from the coronavirus, establishes that the authorities may adopt, within the scope of their powers, the import and distribution of essential medications to assist in combating the pandemic, provided that such measures are determined based on scientific evidence. This same law also establishes that the bids for the purchase or contracting of goods, services and supplies destined to cope with the public health emergency are waived. ${ }^{27}$ It determines that all purchases or contracts made in the period must be made available on a specific official website, as provided for in the Access to Information Law (Federal Law 12,527/2011). ${ }^{28}$

For the bodies under the jurisdiction of the Court of Auditors of the State of Rio Grande do Sul (TCE-RS), the availability of such data is made on the TCE-RS website through the LicitaCon system. ${ }^{29}$ The diverse information and documents available on the website are included by the very bodies responsible for opening the bidding processes, and must comply with Resolution No. 1,050/2015, which provides for the sending and availability of documents, data and information related to bids and administrative contracts, and Normative Instruction No. $13 / 2017$, which establishes the deadlines and rules pertinent to the sending of information and other documents that feed the LicitaCon System. ${ }^{30,31}$

In view of this scenario, the objective of the study was to assess the quantities and values involved in the emergency contracts formalized by the bodies under jurisdiction to the TCE-RS in the purchase of pharmaceutical products related to possible treatments of COVID-19, and the alignment of these decisions with the best scientific evidence available at the moment.

\section{Methods}

A cross-sectional study with data collection from the contracts registered in the LicitaCon Cidadão system, a public access system that gathers all the purchase processes and contracts formalized by the bodies under jurisdiction of the TCE-RS, such as the municipalities, agencies and hospitals with state administration. 
In order to contribute to the transparency of the measures taken in the pandemic context and to facilitate access to the contracts of the entire state of RS in a single portal, the TCE-RS created in the LicitaCon system the category called "COVID-19 contracts" where all the contracts aimed at coping with the pandemic are gathered. ${ }^{32}$ For the analysis, all the contracts registered in the "COVID-19 contracts" category were assessed until September $19^{\text {th }}, 2020$. For the selection of the contracts, a search filter was applied using the following words or terms: "medication", "pharmacy", "pharmacological material", "hydroxychloroquine", "chloroquine", "ivermectin", "nitazoxanide" and "vitamin".

Contracts containing medication(s) registered in the bid objects were selected. Contracts that did not specify the medication, the value, or the amount of drug required were excluded from the analysis. For the analysis of the medications, contracts whose process result was "in progress", "deserted" and "failed" were excluded. The medications present in the selected bids were included in a list containing the pharmaceutical form, the concentration, the bid amount, the unit value and the total contracted value, and were classified according to the first level of the Anatomical Therapeutic Chemical (ATC) Classification. The pharmaceutical products related to the treatment of COVID-19 were selected for a broader analysis, them being: hydroxychloroquine, chloroquine, ivermectin, nitazoxanide and vitamin D, vitamin C, zinc, oseltamivir and pharmaceutical products containing zinc. Figure 1 shows the flow of contract selection. After selecting the data, the purchase values of each selected medication were assessed in more detail. For each medication, the maximum and minimum purchase value and also the total value invested for the purchase of the medication by the bodies under jurisdiction of the TCE-RS were verified, as well as the relative and absolute values referring to the purchases of the medications.

Figure 1. Flow of the selection of contracts on the LicitaCon Cidadão platform.

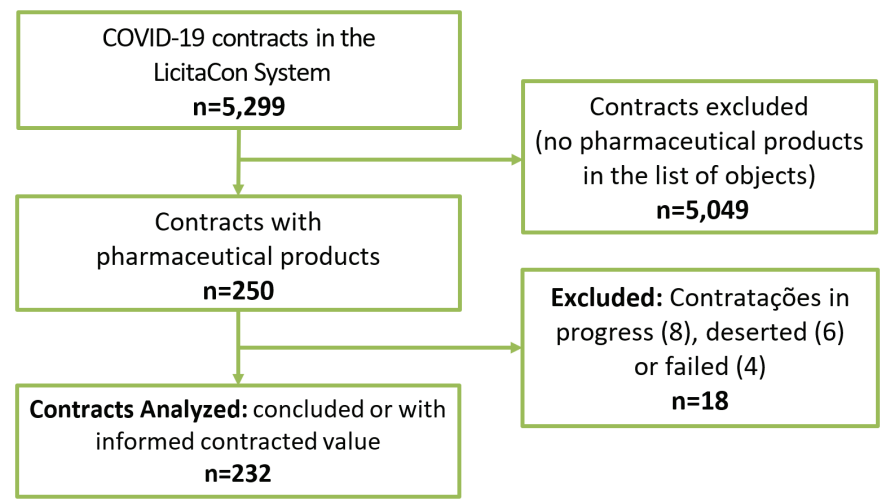

The documents registered in the system referring to each process were accessed to calculate the unit value of the medications bid in boxes or cartons. The values obtained in the collection process were converted from the Brazilian currency to dollars, using the equivalence of the American currency on September $22^{\text {nd }}, 2020$. For the conversion of the values, the currency converter of the Brazilian Central Bank was used, and the date used refers to the first quote made after the final date of data collection. ${ }^{33}$ The 20 municipalities that invested the most in the aforementioned medications were selected, which were separated according to the health macro-region. ${ }^{34}$ The total value of the bids for the medications was divided by the estimated number of inhabitants. ${ }^{35}$

\section{Results}

Until September $19^{\text {th }}, 2020$, a total of 5,299 processes were registered in the "COVID-19 Contracts" tab of the LicitaCon system. Of this total, 250 bids had at least one medication in the list of objects.

A total of 232 contracts were analyzed, formalized by 92 agencies. In all, 738 medications were tendered. Of the medications for the digestive tract and metabolism, the most frequently found were the vitamins, 44 times (6\%), and the mineral supplements, 29 times (3.93\%). Among the medications for blood and hematopoietic organs, antithrombotics, such as enoxaparin, stand out, listed 9 times (1.22\%). For the cardiovascular system, the most commonly bid medications were those used for cardiac therapy, such as norepinephrine, which was bid 9 times (1.22\%). Of the medications belonging to Group $H$, the most frequently found was dexamethasone, with 11 times (1.5\%). The antibacterial agents for systemic use were the medications from Group I most frequently found in the bids, 87 times (11.8\%), with azithromycin being listed 44 times (6\%). Of the medications for the musculoskeletal system, the most frequently bid were the muscle relaxants, such as suxamethonium, found 5 times $(0.7 \%)$, and atracurium, found 3 times $(0.4 \%)$. The most frequently found medications with action on the nervous system were the anesthetics, 26 times (3.52\%), analgesics, 43 times (5.8\%), and psycholeptics, 49 times (6.6\%), such as lithium carbonate, 10 times (1.35\%) and midazolam, 20 times (2.7\%). Among the medications belonging to Group $\mathrm{P}$, the following stand out: hydroxychloroquine, 40 times (5.42\%), nitazoxanide, 23 times (3.12\%), and ivermectin, 80 times (10.84\%). Of the medications acting on the respiratory system, the most frequently found was salbutamol, listed 19 times (2.57\%).

Table 1 presents the bidding data for hydroxychloroquine, chloroquine, ivermectin, nitazoxanide, zinc, vitamin $\mathrm{C}$ and vitamin $D$, grouped according to the main ATC group.

Electronic Auction 4/2020 was carried out by the Intermunicipal Health Consortium (Consórcio Intermunicipal de Saúde, CISA) of the Northeast of the State of Rio Grande for the purchase ivermectin, hydroxychloroquine, zinc sulfate, nitazoxanide and cholecalciferol. From it, the 72 municipalities belonging to the bidding process could purchase the CISA medications, in order to ensure a better purchase price. In order to avoid duplicity of results in the data presented in Table 1, the bids that contracted the CISA were disregarded for the calculation of the quantities, unit value and total value.

Of the 232 bids analyzed, 142 contained at least one of the medications included in Table 2, which represents $61.2 \%$ of the bids. The 142 bids were registered by 80 different bodies, 74 of which are City Halls, representing $14.9 \%$ of the City Halls in RS, which has 497 municipalities. 
Table 1. Bids and values of the medications selected, grouped according to the main ATC group.

\begin{tabular}{|c|c|c|c|c|c|c|}
\hline ATC Class/Medication & Bids & Total & $\begin{array}{l}\text { Mean } \\
\text { price (\$) }\end{array}$ & Minimum price (\$) & Maximum price (\$) & Total value (\$) \\
\hline $\begin{array}{l}\text { Antiparasitics, insecticides and repellent } \\
\text { products }\end{array}$ & $147(57 \%)$ & & & & & \\
\hline Ivermectin 6 mg, pill & $80^{1}$ & 528,132 & 0.6148 & 0.110 & 1.290 & $241,794.81$ \\
\hline Hydroxychloroquine 400 mg, pill & $38^{2}$ & 213,397 & 0.666 & 0.259 & 4.049 & $71,096.78$ \\
\hline Nitazoxanide 500 mg, pill & $13^{3}$ & 93,460 & 0.806 & 0.528 & 1.286 & $65,216.13$ \\
\hline Nitazoxanide 20 mg/ml, oral susp., 100 mL vial & 5 & 340 & 4.331 & 1.815 & 5.310 & $1,385.41$ \\
\hline Nitazoxanide 20 mg/ml, oral susp., 45 mL vial & 5 & 710 & 2.716 & 2.050 & 4.200 & $1,751.2562$ \\
\hline Chloroquine 150 mg, pill & 3 & 57,000 & 0.237 & 0.090 & 0.090 & $5,895.64$ \\
\hline Hydroxychloroquine 200 mg, pill & 2 & 1,750 & 1.458 & 0.340 & 2.577 & $1,155.00$ \\
\hline Chloroquine diphosphate $250 \mathrm{mg}$, pill & 1 & 1,800 & 0.276 & - & - & 496.97 \\
\hline Chloroquine diphosphate $400 \mathrm{mg}$, pill & 1 & 1,000 & 0.121 & - & - & 121.482 \\
\hline Anti-infectives for systemic use & $45(17 \%)$ & & & & & \\
\hline Azithromycin 500 mg, pill & $36^{3}$ & 418,472 & 0.49 & 0.098 & 1.198 & $170,818.25$ \\
\hline Azithromycin $40 \mathrm{mg} / \mathrm{mL}$, oral susp., $15 \mathrm{~mL}$ vial & 3 & 1,700 & 2.525 & 1.082 & 5.043 & $2,815.25$ \\
\hline $\begin{array}{l}\text { Azithromycin } 500 \text { mg, } \\
\text { injectable sol. }\end{array}$ & 3 & 2,700 & 10.179 & 4.786 & 14.725 & $22,258.83$ \\
\hline Azithromycin $40 \mathrm{mg} / \mathrm{mL}$, oral susp., $22.5 \mathrm{~mL}$ vial & 2 & 150 & 3.703 & 3.560 & 3.847 & 548.33 \\
\hline Oseltamivir 75 mg & 1 & 1,000 & 2.558 & - & - & $2,558.486$ \\
\hline Digestive tract and metabolism & $66(20 \%)$ & & & & & \\
\hline Vitamin D, pill (various dosages) & $25^{2}$ & 84,598 & 0.536 & 0.066 & 1.837 & $38,027.34$ \\
\hline Pharmaceutical products containing zinc, pill & $24^{2}$ & 150,040 & 0.149 & 0.039 & 0.368 & $22,041.12$ \\
\hline Vitamin C, pill (500 mg and $1 \mathrm{~g}$ ) & 4 & 21,520 & 0.107 & 0.083 & 0.145 & $1,961.01$ \\
\hline Others & $12^{3}(5 \%)$ & - & - & - & - & $11,971.43$ \\
\hline Total & $258(100 \%)$ & & & & & $661,913.52$ \\
\hline
\end{tabular}

1: Five municipalities contracted the CISA; 2: Three municipalities contracted the CISA; 3: Two municipalities contracted the CISA. CISA: Intermunicipal Health Consortium (Consórcio Intermunicipal de Saúde) of the Northeast of the State of Rio Grande do Sul. Others: Multivitamins with and without zinc.

Table 2. Data of the cities that most frequently purchased the related medications in Table 1, according to population size, and grouped by health macro-regions.

\begin{tabular}{|c|c|c|c|c|}
\hline Region/City & Population & Medications tendered & Total value (\$) & Per capita value (\$) \\
\hline \multicolumn{5}{|l|}{ Missioneira } \\
\hline Garruchos & 2,886 & ivermectin & $19,796.06$ & 6.858 \\
\hline Santo Augusto & 13,848 & hydroxychloroquine, ivermectin & $25,953.36$ & 1.874 \\
\hline São José do Inhacorá & 2,056 & ivermectin, multivitamin & $2,980.48$ & 1.449 \\
\hline Cotiporã & 3,838 & hydroxychloroquine, ivermectin, vitamin D, zinc & $4,673.75$ & 1.217 \\
\hline Santa Bárbara do Sul & 7,909 & $\begin{array}{l}\text { azithromycin, chloroquine, hydroxychloroquine, ivermectin, } \\
\text { nitazoxanide, vitamin D, zinc }\end{array}$ & $7,081.64$ & 0.894 \\
\hline Senador Salgado Filho & 2,770 & ivermectin & $1,744.92$ & 0.629 \\
\hline Alegria & 3,374 & azithromycin, ivermectin & $2,006.111$ & 0.594 \\
\hline Doutor Maurício Cardoso & 4,462 & azithromycin, ivermectin, vitamin D, zinc, multivitamin & $2,393.88$ & 0.535 \\
\hline Giruá & 15,863 & hydroxychloroquine, ivermectin & $6,474.44$ & 0.408 \\
\hline \multicolumn{5}{|l|}{ North } \\
\hline Marau & 44,858 & azithromycin, hydroxychloroquine, ivermectin & $54,574.90$ & 1.216 \\
\hline Sarandi & 24,763 & hydroxychloroquine, ivermectin, vitamin $D$, zinc & $25,171.40$ & 1.016 \\
\hline $\begin{array}{l}\text { Almirante Tamandaré } \\
\text { do Sul }\end{array}$ & 1,949 & ivermectin, nitazoxanide & $1,504.17$ & 0.770 \\
\hline Seberi & 10,713 & Ivermectin & $8,227.65$ & 0.768 \\
\hline Nova Boa Vista & 1,753 & hydroxychloroquine, ivermectin & 901.91 & 0.513 \\
\hline Soledade & 31,035 & azithromycin, hydroxychloroquine, ivermectin & $14,801.27$ & 0.476 \\
\hline \multicolumn{5}{|l|}{ Metropolitan } \\
\hline Parobé & 58,858 & azithromycin, ivermectin & $37,545.32$ & 0.637 \\
\hline \multicolumn{5}{|l|}{ Midwest } \\
\hline Mata & 4,797 & ivermectin & $2,576.89$ & 0.537 \\
\hline Jari & 3,486 & hydroxychloroquine, ivermectin, nitazoxanide, vitamin D & $1,766.46$ & 0.506 \\
\hline \multicolumn{5}{|l|}{ South } \\
\hline São José do Norte & 27,721 & ivermectin, vitamin $D$, zinc & $13,665.56$ & 0.493 \\
\hline
\end{tabular}


Table 3. Data of the 20 cities that most frequently purchased the related medications in Table 2, according to health macro-regions.

\begin{tabular}{|c|c|c|c|}
\hline Region/City & Population (inhab.) & Medications tendered & Total value (\$) \\
\hline \multicolumn{4}{|l|}{ Metropolitan } \\
\hline Canoas & 348,208 & azithromycin, chloroquine, hydroxychloroquine, ivermectin, nitazoxanide & $91,318.63$ \\
\hline Parobé & 58,858 & azithromycin, ivermectin & $37,545.32$ \\
\hline Campo Bom & 69,458 & azithromycin, chloroquine, ivermectin & $25,345.56$ \\
\hline Sapiranga & 80,037 & azithromycin, ivermectin & $22,167.72$ \\
\hline Taquara & 57,584 & azithromycin, ivermectin & $14,345.93$ \\
\hline Estância Velha & 50,672 & azithromycin & 7,717.79 \\
\hline \multicolumn{4}{|l|}{ North } \\
\hline Marau & 44,858 & azithromycin, hydroxychloroquine, ivermectin & $54,574.90$ \\
\hline Sarandi & 24,763 & hydroxychloroquine, ivermectin, vitamin D, zinc & $25,171.45$ \\
\hline Soledade & 31,035 & azithromycin, hydroxychloroquine, ivermectin & $14,801.27$ \\
\hline Passo Fundo & 204,722 & hydroxychloroquine, ivermectin & $12,242.08$ \\
\hline Seberi & 10,713 & ivermectin & $8,227.65$ \\
\hline Carazinho & 62,265 & hydroxychloroquine, zinc & $6,893.35$ \\
\hline \multicolumn{4}{|l|}{ Missioneira } \\
\hline Santo Augusto & 13,848 & hydroxychloroquine, ivermectin & $25,953.36$ \\
\hline Garruchos & 2,886 & ivermectin & $19,796.06$ \\
\hline Santo Ângelo & 77,568 & azithromycin, hydroxychloroquine, ivermectin, nitazoxanide & $16,510.24$ \\
\hline São Borja & 60,019 & hydroxychloroquine, ivermectin, vitamin C, vitamin D, zinc & $10,399.60$ \\
\hline Santa Bárbara do Sul & 7,909 & $\begin{array}{l}\text { azithromycin, chloroquine, hydroxychloroquine, ivermectin, nitazoxanide, vitamin D, } \\
\text { zinc }\end{array}$ & $7,081.64$ \\
\hline \multicolumn{4}{|c|}{ 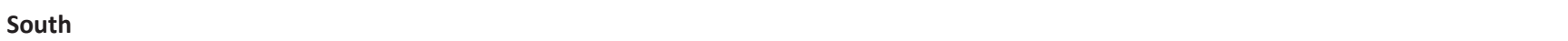 } \\
\hline São José do Norte & 27,721 & ivermectin, vitamin $\mathrm{D}$, zinc & $13,665.57$ \\
\hline \multicolumn{4}{|l|}{ Serra } \\
\hline Gramado & 36,555 & ivermectin & $10,859.76$ \\
\hline Bento Gonçalves & 121,803 & hydroxychloroquine, ivermectin & $7,771.17$ \\
\hline
\end{tabular}

\section{Discussion}

The $\$ 661,913.52$ spent for the purchase of medications without adequate scientific evidence for the treatment of COVID-19 by the bodies under jurisdiction of the TCE-RS help to elucidate the way in which public managers directed the funds to face the pandemic in the state of RS. $61.2 \%$ of the medications purchased in the analyzed period are related to ineffective treatments for COVID19 and which were advocated by rulers and health professionals, as well as widely publicized in the media and social networks.

There is no way of specifying what actually led each body to purchase the medications without adequate scientific evidence for the treatment of COVID-19. The hypotheses are innumerable: pressure from the population, pressure from physicians and even political positioning since, in Brazil, the issue was extremely biased by politics. ${ }^{23-26}$ In this respect, the posture of the Brazilian President stands out, who in countless public events advocated the use of chloroquine/hydroxychloroquine for the treatment of COVID-19, which may have influenced the purchase of the medications and the popular pressure to receive such treatments. ${ }^{36-38}$

According to the WHO, the COVID-19 pandemic has been accompanied by a major infodemic, characterized by excess of information on a subject matter, which multiplies exponentially in a short period of time due to a specific event, such as the pandemic. Therefore, a lot of information that comes up is rumors, misinformation and manipulation of information with a dubious intent, which spread rapidly with the help of the social networks. ${ }^{39}$ A survey carried out by the São Paulo Medical Association showed that $48.9 \%$ of the physicians interviewed believe that the disclosure of fake news negatively interferes in coping with COVID-19, as some patients or family members exert pressure for treatments without scientific proof. ${ }^{40}$

Recently, in October 2020, the WHO published preliminary results from the Solidarity Study, the largest Randomized Clinical Trial (RCT) in the world on possible treatments for COVID-19, in which different medications are being evaluated. The study involved almost 13,000 patients, in 500 hospitals from 30 countries, and the results presented, referring to six months of follow-up, indicate that hydroxychloroquine does not show any benefit for reducing hospitalization time and preventing deaths due to COVID-19. ${ }^{41}$ Prior to this study, others have already indicated the absence of benefit in the use of chloroquine and hydroxychloroquine for COVID-19, such as RECOVERY, an RCT developed in England with more than 1,500 patients, which released the preliminary results showing that there was no reduction in the mortality of hospitalized patients in the group that received hydroxychloroquine after 28 days. In addition, the patients who received the medication presented higher risks for the need of invasive mechanical ventilation or death. ${ }^{42}$

Also in October 2020, the Ministry of Science, Technology and Innovations (Ministério da Ciência, Tecnologia e Inovações, MCTI) released a pre-print containing the results of an RCT with 392 patients to assess the efficacy of nitazoxanide for the treatment of COVID-19. According to the results presented, there was no significant difference in symptom reduction between the group that received nitazoxanide and the placebo group after five days of therapy, although there was a significant reduction in the viral load in the group that received the medication. ${ }^{43}$ All nitazoxanide purchases presented in this study precede the publication of 
such results. Despite this, the results do not warrant using the medication for the treatment of COVID-19, since the study has not yet been assessed by peers.

The WHO stated its position on the use of medications without adequate scientific evidence for the treatment of COVID-19. Regarding chloroquine/hydroxychloroquine, the guideline is that it should only be used in registered, approved and ethically accepted clinical studies, since the scientific evidence favorable to the use of the medications is insufficient and that most research studies show that there is no benefit for the treatment of COVID$19 .{ }^{44}$ In the case of ivermectin, the WHO strongly discourages its use for any purpose other than those duly approved by the regulatory bodies. The WHO emphasizes that the medication was excluded from the Solidarity trial and that the Committee of Experts on Mectizan ${ }^{\circledR}$ (ivermectin) stated that the evidence of viral load reduction in vitro is not sufficient to indicate that the drug will bring clinical benefits to patients with COVID-19, in view of the high dosages, higher than those approved by the FDA. ${ }^{45}$

Regarding the use of antibiotics, the WHO recommends that they should not be prescribed for suspected or confirmed COVID-19 patients unless there is clinical suspicion of bacterial infection, as the evidence points to a low number of patients with bacterial coinfection. ${ }^{8}$ According to the data available up to date, less than $10 \%$ of the patients with COVID-19 present bacterial co-infection. ${ }^{46-49}$ The position is consistent with the rational use of antimicrobials, considering that bacterial resistance is a growing threat to public health in the world and that the inappropriate use of antibiotics is the main responsible for the selection of new resistances. ${ }^{50,51}$

Even though such medications are registered by the ANVISA and have the safety profiles known for the approved treatments, using them for a new disease without conducting controlled studies is risky. Chloroquine and hydroxychloroquine are medications with known adverse reactions, such as the occurrence of retinopathies and cardiac arrhythmia, caused by the prolongation of the QT interval. ${ }^{52,53}$ Bearing in mind that the usual dosing schedules for ivermectin treatments usually involve a single dose of the medication, little is known about its use for longer periods of time and about the adverse reactions involved in these situations ${ }^{54} \mathrm{At}$ the usual doses, adverse reactions related to the use of ivermectin are fever, myalgia, itching, headaches and dizziness. ${ }^{55}$ And in relation to nitazoxanide, there are abdominal pains, headaches and nausea. ${ }^{56}$ By exposing more patients to these medications, the chances of adverse reactions and intoxications caused by the drugs increase.

Following the guidelines of the WHO and the National Commission for the Incorporation of Technologies in the SUS (Comissão Nacional de Incorporação de Tecnologias, CONITEC), which evaluates scientific studies referring to the efficacy, accuracy, effectiveness and safety of medications to be incorporated into SUS, the elaboration of documents organized by the MS for the management of COVID-19 should also have taken into account the most robust scientific evidence available to date. ${ }^{57}$ The CONITEC is responsible for the elaboration of Clinical Protocols and Therapeutic Guidelines (Protocolos Clínicos e Diretrizes Terapêuticas, PCDTs), important to assist in the decisionmaking process in the clinical practice, and of the National List of Medications (Relação Nacional de Medicamentos, RENAME), which collaborates for the promotion of the Rational Use of Medications (RUM) and for the rationalization of the invested costs. ${ }^{58}$

Despite the difficulties imposed by the pandemic, the RUM must be recommended in the clinical practice, so that the appropriate medication is prescribed, in the adequate dose and for the correct period of time, at the lowest cost for the patient and the community. The use of medications in a non-rational fashion can result in risks to the patient's health, in addition to wasting financial resources. ${ }^{59}$ In the case of COVID-19, the use of medications with the promise of treatment and cure can result in the reduction of effective preventive measures against the transmission of the disease, such as social distancing and the use of masks. ${ }^{60}$ In addition, on average, $80 \%$ of the patients heal spontaneously without need for hospitalization. ${ }^{8}$ Using any medication in these cases can give the false impression of a cure from the treatment performed when, in fact, it was merely the outcome that would occur with or without intervention.

One of the best ways to use scientific evidence for individual and collective health is the exercise of Evidence-Based Health $(E B H)$ in the clinical practice, characterized by the use of clinical epidemiology to support decision-making in the health teams. Thus, the actions carried out by the professionals are the result of the integration of technical knowledge, clinical practice, the best scientific evidence available and the patients' values and particularities. ${ }^{61}$ Therefore, it is necessary that health professionals have skills and competences to evaluate scientific articles, in order to develop critical reading, capable of recognizing the methodological weaknesses and biases of the studies, so that the available data are used and applied in an adequate manner.

In addition to that, the implementation of Pharmacy and Therapy Commissions (PTCs) in the municipalities can assist in the decision-making processes about public investments intended for health, such as the purchase of medications. Although not provided by law in Brazil, the WHO recommends the organization of PTCs in different spheres, composed of a multidisciplinary team, with pharmacists, physicians, nurses, dentists, and other professionals that may be necessary. ${ }^{62}$ One of the actions of a PTC in a municipality can be the elaboration of clinical protocols for the treatment of diseases, helping to direct and rationalize public investments for efficient treatments and measures.

Finally, an important professional to aid in the mitigation of fake news and in the health education process is the pharmacist. Since 2014, thanks to Law 13,021, every pharmacy must have a full-time pharmacist; pharmacists are the health professionals most accessible to the population, who can reach out to them to solve doubts about medications, diseases and preventive measures for COVID-19 and other health problems. ${ }^{63}$ Therefore, in order to play this important role with the community, in addition to staying informed about the best scientific evidence available, it is essential that pharmacists develop skills to communicate them clearly to the population.

This study has some limitations: Although it is mandatory to make all contracts available on the LicitaCon platform, there is no way to guarantee that this was in fact observed, since it is up to the body under jurisdiction of the TCE-RS to feed the system. It is also important to note that the state of RS received chloroquine directly from the MS, which can explain the fact that hydroxychloroquine and chloroquine have been less tendered than ivermectin. According to the State Health Secretariat, the state of RS received 25,000 chloroquine pills in May. ${ }^{64}$ And, in July, the MS delivered 47,000 chloroquine pills to the state, as well as 1.1 million oseltamivir pills. ${ }^{65}$ Another limitation is related to the fact that data collection was carried out only by one researcher. In addition, many of the medications tendered may have been purchased for the management of diseases other than COVID-19, such as azithromycin, which, despite being included in treatment protocols for COVID-19, is also an antibiotic widely used in the clinical practice for the treatment of other infections. 


\section{Conclusion}

According to the survey presented in this study, $\mathrm{R} \$ 661,913.52$ from the public coffers were spent on medications that lack adequate scientific evidence for the treatment of COVID-19. Such financial resources could have been directed to other measures that present some real benefit to control the pandemic, such as expanding testing, distribution of masks to the population, hiring of health professionals to qualify care services, and purchase of PPE to ensure better safety for the professionals. In addition, in times when the infodemic is present and contaminates opinions and news, the efforts made by the professionals and teams in health education actions must be redoubled, regulatory bodies must be constantly consulted, and science must be respected. It is urgent that, as a society, public decisions and investments consider scientific evidence, and that the clinical practice conducted by the health professionals is based on concrete and robust data.

\section{Funding sources}

The research did not receive funding for its conduction.

\section{Collaborators}

NAP and DG: Conception, design, data analysis and interpretation. Writing of the article and relevant critical review of the intellectual content. NAP: Data collection.

\section{Conflict of interest statement}

The authors declare that there are no conflicts of interest regarding this article.

\section{References}

1. Organização Pan-Americana da Saúde. OMS afirma que COVID19 é agora caracterizada como pandemia. Avaliable in: https:// www.paho.org/bra/index.php?option=com_content\&view=article\&id=6120:oms-afirma-que-covid-19-e-agora-caracterizada-como-pandemia\&Itemid=812. Accessed on: 03 Dec 2020.

2. World Health Organization. Timeline: WHO's COVID-19 response. Avaliable in: https://www.who.int/emergencies/diseases/novel-coronavirus-2019/interactive-timeline?gclid=CjOKCQjwit_8BRCoARIsAIx3Rj7HxqBrqifw1a9Nokr2281CkKuL262FOgZ3jaZNI2f9uJvbgEG4QilaAuwyEALw_wcB\#event-17. Accessed on: 03 Dec 2020.

3. Brasil. Ministério da Saúde. Painel Coronavírus. Avaliable in: https://covid.saude.gov.br/. Accessed on: 03 Dec 2020.

4. World Health Organization. Coronavirus Disease (COVID-19) Dashboard. Avaliable in: https://covid19.who.int/table. Accessed on: 28 Oct 2020.

5. ClinicalTrials.gov. Drug Interventions related to search results. Avaliable in: https://clinicaltrials.gov/ct2/results/ browse?cond=covid-19\&brwse=intr_alpha_all. Accessed on: 04 Dec 2020.

6. Serafin MB, Bottega A, Foletto VS, et al. Drug repositioning is an alternative for the treatment of coronavirus COVID-19.
Int J Antimicrob Agents. 2020;55(6):105969. DOI: 10.1016/j. ijantimicag.2020.105969.

7. Organização Pan-Americana da Saúde. Atendimento domiciliar para pacientes com suspeita ou confirmação de COVID-19 e gerenciamento de seus contatos. Avaliable in: https://iris. paho.org/bitstream/handle/10665.2/52615/OPASWBRACOVID-1920102_por.pdf?sequence $=1$ \&isAllowed $=y$. Accessed on: 28 Oct 2020.

8. Organização Pan-Americana da Saúde. Manejo Clínico da COVID-19. Avaliable in: https://iris.paho.org/bitstream/ handle/10665.2/52285/OPASWBRACOVID1920075_por.pdf? sequence=1\&isAllowed=y. Accessed on: 28 Oct 2020 .

9. Yao X, Ye F, Zhang $\mathrm{M}$, et al. In Vitro Antiviral Activity and Projection of Optimized Dosing Design of Hydroxychloroquine for the Treatment of Severe Acute Respiratory Syndrome Coronavirus 2 (SARS-CoV-2). Clin Infect Dis. 2020;71(15):732739. DOI: 10.1093/cid/ciaa237.

10. Gautret P, Lagier JC, Parola P, et al. Hydroxychloroquine and azithromycin as a treatment of COVID-19: results of an open-label non-randomized clinical trial. Int J Antimicrob Agents. 2020;56(1):105949. DOI: 10.1016/j.ijantimicag.2020.105949.

11. The New York Times. With Minimal Evidence, Trump Asks F.D.A. to Study Malaria Drugs for Coronavirus. Avaliable in: https://www.nytimes.com/2020/03/19/health/coronavirus-drugs-chloroquine.html. Accessed on: 20 Oct 2020.

12. Uol. Bolsonaro mostra remédio feito com hidroxicloroquina em reunião do G20. Avaliable in: https://noticias.uol.com. br/saude/ultimas-noticias/redacao/2020/03/26/bolsonaro-mostra-remedio-feito-com-hidroxicloroquina-em-reuniao-do-g20.htm. Accessed on: 25 Oct 2020.

13. Folha de São Paulo. Pacientes que usam hidroxicloroquina já não acham o remédio em farmácias. Avaliable in: https:// www1.folha.uol.com.br/equilibrioesaude/2020/03/pacientes-que-usam-hidroxicloroquina-ja-nao-acham-o-remedio-em-farmacias.shtml. Accessed on: 20 Oct 2020.

14. Brasil. Ministério da Saúde. Agência Nacional de Vigilância Sanitária (ANVISA). RDC no 351 de 20 de março de 2020. Dispõe sobre a atualização do Anexo I (Listas de Substâncias Entorpecentes, Psicotrópicas, Precursoras e Outras sob Controle Especial) da Portaria SVS/MS no 344 de 12 de maio de 1998 e dá outras providências. Brasília: Diário Oficial [da] República Federativa do Brasil, 2020.

15. Caly L, Druce JD, Catton MG, et al. The FDA approved drug ivermectin inhibits the replication of SARS-CoV-2 in vitro. Antiviral Res. 2020;178:104787. DOI: 10.1016/j.antiviral.2020.104787.

16. Pepperrell $\mathrm{T}$, Pilkington $\mathrm{V}$, Owen $\mathrm{A}$, et al. Review of safety and minimum pricing of nitazoxanide for potential treatment of COVID-19. J Virus Erad. 2020;6(2):52-60. DOI: 10.1016/ S2055-6640(20)30017-0.

17. Brasil. Ministério da Saúde. Agência Nacional de Vigilância Sanitária (ANVISA). RDC no 405 de 22 de julho de 2020. Estabelece as medidas de controle para os medicamentos que contenham substâncias constantes do Anexo I desta Resolução, isoladas ou em associação, em virtude da Emergência de Saúde Pública de Importância Internacional (ESPII) rela- 
cionada ao novo Coronavírus (SARS-CoV-2). Brasília: Diário Oficial [da] República Federativa do Brasil, 2020.

18. Brasil. Ministério da Saúde. Agência Nacional de Vigilância Sanitária (ANVISA). RDC no 420 de 1ㅇ de setembro de 2020. Dispõe sobre a atualização do Anexo I da RDC no 405 de 22 de julho de 2020. Brasília: Diário Oficial [da] República Federativa do Brasil, 2020

19. Brasil. Ministério da Saúde. Secretaria de Ciência, Tecnologia, Inovação e Insumos Estratégicos em Saúde. Departamento de Assistência Farmacêutica e Insumos Estratégicos. Nota Informativa no 5/2020-DAF/SCTIE/MS. Uso da Cloroquina como terapia adjuvante no tratamento de formas graves do COVID19. Brasília, DF, 2020

20. Brasil. Ministério da Saúde. Orientações do Ministério da Saúde para Manuseio Medicamentoso Precoce de Pacientes com Diagnóstico da COVID-19. Brasília, DF, 2020.

21. Brasil. Ministério da Saúde. Ministério da Saúde amplia orientações para uso da cloroquina. Avaliable in: https://www.gov.br/ saude/pt-br/assuntos/noticias/ministerio-da-saude-amplia-orientacoes-para-uso-da-cloroquina-2. Accessed on: 20 Oct 2020.

22. Brasil de Fato. Por que o "kit-Covid" faz sucesso mesmo sem base científica? Avaliable in: https://www.brasildefators.com. br/2020/07/29/por-que-o-kit-covid-faz-sucesso-mesmosem-base-cientifica. Accessed on: 11 Oct 2020

23. G1 Rio Grande do Sul. Médicos e prefeituras do RS adotam remédios sem eficácia comprovada para tratamento da Covid-19. Avaliable in: https://g1.globo.com/rs/rio-grandedo-sul/noticia/2020/07/14/medicos-e-prefeituras-do-rs-adotam-remedios-sem-eficacia-comprovada-para-tratamento-da-covid-19.ghtml. Accessed on: 11 Oct 2020

24. Agência Brasil. Tratamento precoce contra Covid-19 é defendido por médicos para aumentar chance de cura. Avaliable in: https:// www.gov.br/pt-br/noticias/saude-e-vigilancia-sanitaria/2020/08/ tratamento-precoce-contra-covid-19-e-defendido-por-medicos-para-aumentar-chance-de-cura. Accessed on: 15 Oct 2020.

25. Agência Brasil. Covid-19: Bolsonaro se reúne com médicos que apoiam uso da cloroquina. Avaliable in: https://agenciabrasil.ebc.com.br/saude/noticia/2020-09/covid-19-bolsonaro-se-reune-com-medicos-que-apoiam-uso-da-cloroquina. Accessed on: 20 Oct 2020

26. Estadão. Apelo por distribuição de remédios cita medicamentos sem eficácia comprovada contra o Coronavírus. Avaliable in: https:// politica.estadao.com.br/blogs/estadao-verifica/apelo-por-distribuicao-de-remedios-cita-medicamentos-sem-eficacia-comprovada-contra-o-coronavirus/. Accessed on: 11 Oct 2020.

27. Brasil. Presidência da República. Lei no 13.979 de 6 de fevereiro de 2020. Dispõe sobre as medidas para enfrentamento da emergência de saúde pública de importância internacional decorrente do coronavírus responsável pelo surto de 2019. Brasília: Diário Oficial [da] República Federativa do Brasil, 2020.

28. Brasil. Presidência da República. Lei no 12.527 de 18 de novembro de 2011. Regula o acesso a informações previsto no inciso XXXIII do art. 5으, no inciso II do § 3 ㅇ do art. 37 e no § 2ㅇ do art. 216 da Constituição Federal; altera a Lei no 8.112, de 11 de dezembro de 1990; revoga a Lei no 11.111, de 5 de maio de 2005, e dispositivos da Lei no 8.159, de 8 de janeiro de 1991; e dá outras providências. Brasília: Diário Oficial [da]
República Federativa do Brasil, 2011.

29. Tribunal de Contas do Estado do Rio Grande do Sul. LicitaCon Cidadão. Avaliable in: http://www1.tce.rs.gov.br/aplicprod/ $f ? p=50500: 1: 106759066834443$. Accessed on: 28 Jul 2020.

30. Tribunal de Contas do Estado do Rio Grande do Sul. Atos Normativos. Resolução no 1050 de 2015. Dispõe sobre o envio e a disponibilização, por meio do Sistema de Licitações e Contratos - LicitaCon, de dados, informações e documentos relativos a licitações e contratos administrativos dos poderes, órgãos e entidades jurisdicionados do Tribunal de Contas do Estado do Rio Grande do Sul. Rio Grande do Sul, 2015.

31. Tribunal de Contas do Estado do Rio Grande do Sul. Atos Normativos. Instrução Normativa no 13 de 2017. Dispõe sobre os prazos e demais regras técnicas relativas à alimentação do Sistema de Licitações e Contratos - LicitaCon pelos órgãos e entidades jurisdicionados do Tribunal de Contas do Estado do Rio Grande do Sul. Rio Grande do Sul, 2017.

32. Tribunal de Conta do Estado do Rio Grande do Sul. TCE-RS disponibiliza dados sobre contratações para o enfrentamento à Covid-19. Avaliable in: http://www1.tce.rs.gov.br/portal/ page/portal/tcers/administracao/gerenciador_de_conteudo/noticias/TCERS\%20disponibiliza\%20dados\%20sobre\%20 contrata\%E7\%F5es\%20para\%20o\%20enfrentamento\%20 \%E0\%20Covid-19. Accessed on: 28 Jul 2020.

33. Banco Central do Brasil. Conversor de Moedas. Avaliable in: https://www.bcb.gov.br/conversao. Accessed on: 26 Fem 2021.

34. Conselho das Secretarias Municipais de Saúde do Rio Grande do Sul (COSEMSRS). Regiões de Saúde. Avaliable in: https://www. cosemsrs.org.br/regioes-de-saude. Accessed on: 17 Oct 2020.

35. Brasil. Instituto Brasileiro de Geografia e Estatística (IBGE). Estimativas populacionais para os municípios e para as Unidades da Federação para 10 de julho de 2020. Avaliable in: https:// www.ibge.gov.br/estatisticas/sociais/populacao/9103-estimativas-de-populacao.html?edicao $=28674 \& \mathrm{t}=$ resultados Accessed on: 20 Oct 2020

36. Estado de Minas. Bolsonaro cita hidroxicloroquina em tratamento e ignora falta de comprovação: "E daí?". Avaliable in: https://www.em.com.br/app/noticia/politica/2020/09/24/ interna politica, $1188731 /$ bolsonaro-cita-cloroquina-em-tratamento-e-ignora-falta-de-comprovacao.shtml. Accessed on: 20 Oct 2020.

37. Instituto de Ciência, Tecnologia e Qualidade (ICTQ). "Cloroquina não tem efeito colateral" afirma Bolsonaro. Avaliable in: https://www.ictq.com.br/politica-farmaceutica/1328-cloroquina-nao-tem-efeito-colateral-afirma-bolsonaro. Accessed on: 20 Oct 2020.

38. Estado de Minas. Bolsonaro a franceses, em Brasília: "No Brasil, cloroquina tem $100 \%$ de cura". Avaliable in: https://www. em.com.br/app/noticia/politica/2020/10/24/interna_politica,1197790/bolsonaro-a-franceses-em-brasilia-brasil-cloroquina-tem-100-cura.shtml. Accessed on: 28 Oct 2020.

39. Organização Pan-Americana da Saúde. Departamento de Evidências e Inteligência para Ações em Saúde. Entenda a infodemia e a desinformação na luta contra a COVID-19. Avaliable in: https://iris.paho.org/bitstream/handle/10665.2/52054/ Factsheet-Infodemic_por.pdf?sequence=14. Accessed on: 20 Oct 2020. 
40. Associação Paulista de Medicina. Os médicos e a pandemia do novo coronavírus (COVID-19). Avaliable in: http://associacaopaulistamedicina.org.br/files/2020/pesquisa-apm-medicos-covid-19-jun2020.pdf. Accessed on: 11 Oct 2020.

41. Pan H, Peto R, Karim QA, et al. WHO Solidarity trial consortium. Repurposed antiviral drugs for COVID-19- interim WHO SOLIDARITY trial results. MedRxiv, 2020 October 15. DOI: 10.1101/2020.10.15.20209817.

42. Horby $P$, Mafham M, Linsell L, et al. Effect of hydroxychloroquine in hospitalized patients with COVID-19: preliminary results from a multi-centre, randomized, controlled trial MedRxiv, 2020 July 15. DOI: 10.1101/2020.07.15.20151852.

43. Rocco PRM; Silva PL, Cruz FF, et al. Early use of nitazoxanide in mild Covid-19 disease: randomized, placebo controlled trial. MedRxiv, 2020 Oct 23. DOI: 10.1101/2020.10.21.20217208.

44. Organização Pan-Americana da Saúde. Escritório da OPAS e da OMS no Brasil. Folha informativa COVID-19. Avaliable in: https://.paho.org/pt/covid19\#cloroquina. Accessed on: 23 Oct 2020.

45. Organização Pan-Americana da Saúde. Recomendação sobre o uso de ivermectina no tratamento de COVID-19. Avaliable in: https://iris.paho.org/bitstream/handle/10665.2/52462/ OPASIMSCDECOVID19200033_por.pdf?sequence=1\&isAIlowed=y. Accessed on: 23 Oct 2020.

46. Chen $N$, Zhou M, Dong $X$, et al. Epidemiological and clinical characteristics of 99 cases of 2019 novel coronavirus pneumonia in Wuhan, China: a descriptive study. Lancet. 2020;395(10223):507-513. DOI: 10.1016/S01406736(20)30211-7.

47. Vaughn VM, Gandhi T, Petty LA, et al. Empiric Antibacterial Therapy and Community-onset Bacterial Co-infection in Patients Hospitalized with COVID-19: A Multi-Hospital Cohort Study. Clin Infect Dis. 2020; ciaa1239. DOI: 10.1093/cid/ ciaa1239.

48. Mody L, Washer LL, Kaye KS, et al. Multidrug-resistant Organisms in hospitals: what is on patient hands and in their rooms. Clin Infect Dis. 2019;69(11):1837-1844. DOI: 10.1093/ $\mathrm{cid} / \mathrm{ciz092}$

49. Lansbury L, Lim B, Baskaran V, et al. Co-infections in people with COVID-19: a systematic review and meta-analysis. J Infect. 2020;81(2):266-275. DOI:10.1016/j.jinf.2020.05.046.

50. World Health Organization. Antimicrobial resistance: global report on surveillance. 2014. Avaliable in: https://apps.who. int/iris/bitstream/handle/10665/112642/9789241564748 eng.pdf?sequence=1. Accessed on: 26 Oct 2020 .

51. Brasil. Ministério da Saúde. Secretaria de Ciência, Tecnologia e Insumos Estratégicos. Uso Indiscriminado de Antimicrobianos e Resistência Microbiana no 03. 2010. Avaliable in: https://www.paho.org/bra/index.php?option=com_docman\&view=download\&alias=1348-uso-indiscriminado-antimicrobianos-e-resistencia-microbiana-boletim-n-03-8\&category_slug=uso-racional-medicamentos-685\&Itemid=965. Accessed on: 26 Jul 2020.

52. Drugs.com. Hydroxychloroquine Side Effects. For Healthcare Professionals. Avaliable in: https://www.drugs.com/sfx/ hydroxychloroquine-side-effects.html\#for-professionals. Accessed on: 27 Oct 2020.
53. Drugs.com. Chloroquine Side Effects. For Healthcare Professionals. Avaliable in: https://www.drugs.com/sfx/chloroquine-side-effects.html\#for-professionals. Accessed on: 27 Oct 2020.

54. Drugs.com. Ivermectin Dosage. Avaliable in: https://www.drugs. com/dosage/ivermectin.html. Accessed on: 27 Oct 2020.

55. Drugs.com. Ivermectin Side Effects. For Healthcare Professionals. Avaliable in: https://www.drugs.com/sfx/ivermectin-side-effects.html\#for-professionals. Accessed on: 27 Oct 2020.

56. Drugs.com. Nitazoxanide Side Effects. For Healthcare Professionals. Avaliable in: https://www.drugs.com/sfx/nitazoxanide-side-effects.html\#for-professionals. Accessed on: 27 Oct 2020.

57. Brasil. Ministério da Saúde. Comissão Nacional de Incorporação de Tecnologias no Sistema Único de Saúde (CONITEC). Entenda a Conitec. Avaliable in: http://conitec.gov.br/entenda-a-conitec-2. Accessed on: 27 Oct 2020.

58. Brasil. Ministério da Saúde. Secretaria de Ciência, Tecnologia, Inovação e Insumos Estratégicos em Saúde. Departamento de Assistência Farmacêutica e Insumos Estratégicos. Relação Nacional de Medicamento Essenciais (RENAME) 2020. Brasília, DF, 2020.

59. Organização Pan-Americana da Saúde. Representação Brasil. Uso Racional de Medicamentos: fundamentação em condutas terapêuticas e nos macroprocessos da Assistência Farmacêutica. 2015. Avaliable in: https://www.paho.org/bra/index.php?option=com_docman\&view=download\&alias=1518-apresentacao-8\&category_slug=serie-uso-racional-medicamentos-284\&Itemid=965. Accessed on: 12 Oct 2020.

60. Erku DA, Belachew SA, Abrha S, et al. When fear and misinformation go viral: Pharmacists' role in deterring medication misinformation during the 'infodemic' surrounding COVID19 [published online ahead of print, 2020 May 1]. Res Social Adm Pharm. 2020;S1551-7411(20)30455-1. DOI: 10.1016/j. sapharm.2020.04.032.

61. Brasil. Ministério da Saúde. Diretrizes Metodológicas: Sistema GRADE: Manual de graduação da qualidade da evidência e força de recomendação para tomada de decisão em saúde. 2014. Avaliable in: http://bvsms.saude.gov.br/bvs/ publicacoes/diretrizes_metodologicas_sistema_grade.pdf. Accessed on: 26 Oct 2020.

62. Grochocki MH, Oliveira JC, Pinheiro RM. Seleção de Medicamentos. In: Farias M, Diehl E, Buendgens F, et al. (ed). Assistência Farmacêutica no Brasil: Política, Gestão e Clínica. Volume 3. Florianópolis: Editora da UFSC, 2016: 53-146.

63. Brasil. Presidência da República. Lei no 13021 de 08 de agosto de 2014. Dispõe sobre o exercício e a fiscalização das atividades farmacêuticas. Brasília: Diário Oficial [da] República Federativa do Brasil, 2014.

64. Rio Grande do Sul. Secretaria de Saúde do Estado. Estado distribui cloroquina para o tratamento de casos críticos de Covid19. Avaliable in: https://saude.rs.gov.br/estado-distribui-cloroquina-para-o-tratamento-de-casos-criticos-de-covid-19. Accessed on: 11 Oct 2020.

65. Brasil. Ministério da Saúde. Ministério da Saúde reforça ação pelo enfrentamento à Covid-19 na região Sul. Avaliable in: https://www.gov.br/saude/pt-br/assuntos/noticias/ministerio-da-saude-reforca-acao-pelo-enfrentamento-a-covid-19na-regiao-sul. Accessed on: 11 Oct 2020. 